\title{
A LABORATORY AND IN SITU POSTEXPOSURE FEEDING ASSAY WITH A FRESHWATER SNAIL
}

\author{
VÂnia Correia, Rui Ribeiro,* and Matilde Moreira-Santos \\ Instituto do Mar, Department of Life Sciences, University of Coimbra, Coimbra, Portugal
}

(Submitted 5 April 2013; Accepted 24 May 2013)

\begin{abstract}
Contaminant-driven feeding inhibition has direct and immediate consequences at higher levels of biological organization, by depressing the population consumption and thus hampering ecosystem functioning (e.g., grazing, organic matter decomposition). The present study aimed at developing a short-term laboratory and in situ assay based on the postexposure feeding of the freshwater snail Theodoxus fluviatilis. A method to precisely quantify feeding rates was first developed, consisting of a 3-h feeding period, in darkness, on 150 defrosted nauplii of the brine shrimp Artemia franciscana. Postexposure feeding after a 48-h exposure to cadmium was approximately as sensitive as survival, with the median effective concentration (EC50) and median lethal concentration (LC50) being $85 \mu \mathrm{g} / \mathrm{L}$ and $102 \mu \mathrm{g} / \mathrm{L}$, respectively, and the $20 \%$ effective concentration (EC20) and $20 \%$ lethal concentration (LC20) being $41 \mu \mathrm{g} / \mathrm{L}$ and $77 \mu \mathrm{g} / \mathrm{L}$, respectively. Together, both effects at the LC20 reduced population consumption by 56\%. In situ experiments at reference sites covering broad ranges of current velocity, hardness, conductivity, sediment organic matter content, and sediment particle size distribution revealed the influence of these abiotic conditions on postexposure feeding, in the absence of contamination, to be negligible. The effectiveness of the in situ assay was evaluated at 5 sites contaminated with acid mine drainage. Surviving organisms at the single partially lethal site (37\% mortality) presented a 54\% feeding inhibition relative to the reference, whereas the population consumption would be inhibited by $71 \%$, confirming the integration of survival and feeding to be pertinent for estimating contaminant effects at higher levels of biological organization. Environ Toxicol Chem 2013;32:2144-2152. (C) 2013 SETAC
\end{abstract}

Keywords: Sublethal assay $\quad$ Freshwater toxicity Theodoxus fluviatilis $\quad$ Acid mine drainage Cadmium

\section{INTRODUCTION}

Contaminant-driven feeding inhibition has direct and immediate consequences at higher levels of biological organization, by depressing the population consumption and thus hampering ecosystem functioning (e.g., grazing, organic matter decomposition). Thus, like lethality and avoidance, feeding is an unequivocal, ecologically meaningful response [1-4]. The decrease in feeding rate because of contamination is expected to be fast, general, and quantifiable [2,5-7]. It has been used as a toxicity test endpoint with cladocerans [6,8], amphipods [3,9], decapods [10,11], snails [12,13], polychaetes [7,14,15], midges [14,16], and fish $[17,18]$. If feeding inhibition occurs at contaminant concentrations close to those affecting growth or reproduction, then predicting ecosystem-level effects - taking into account only time-delayed extrapolations from population growth rates-can strongly underestimate risk. In contrast, if feeding inhibition only occurs at partially lethal concentrations, the use of lethality tests alone will also result in a risk underestimation because survivors would eat less than before, leading, along with population downsizing, to an enhanced immediate population consumption inhibition. Under the latter circumstances, an accurate estimation of the effective concentrations inhibiting the population consumption requires an integration of the effective concentrations reducing both individual feeding and survival. Moreover, such integration may well reduce uncertainties in recurrent extrapolations inherent to ecological risk assessment made from the results of relatively simple laboratory assays to quantify effects at the ecosystem level. Relevant contributions to this integration have already been made $[4,13,19]$.

* Address correspondence to rui.ribeiro@zoo.uc.pt

Published online 4 June 2013 in Wiley Online Library

(wileyonlinelibrary.com).

DOI: $10.1002 /$ etc. 2297
In situ toxicity testing has been recognized as a useful approach in ecotoxicity assessments because it can be used, either alongside or instead, to transcend the disadvantages of laboratory tests [20-22]. By exposing organisms in cages at the field, in situ assays incorporate field fluctuations and are less subject to artifacts associated with sample manipulation; in addition, the exposure takes place under more realistic conditions, resulting in a more ecologically relevant exposure scenario that is also cost-effective $[17,21,22]$. Major limitations include the additional stress on test organisms, uncontrolled variables complicating the establishment of causality between exposure and effects, logistic difficulties of deployments in deep or fast-moving waters, availability of adequate reference sites, and vandalism [20,22].

Snails are an integral component of freshwater lotic and lentic communities both as primary consumers and as prey for invertebrate (leeches, flies, and beetles) and vertebrate taxa (fish, birds) [23-25]. Their grazing activity influences the dynamics of the macrophyte epiphyte system by reducing shading and competition for nutrients and through significant shifts in algal communities [26]. Degradation of water quality may be an important factor affecting the declining populations of freshwater snails [12]. The reduction or elimination of a population of snails from a freshwater community may have significant consequences for the structure and function of that community [25].

Theodoxus fluviatilis (L.) is a Prosobranchia Neritidae freshwater snail with a large distribution throughout Europe and Anatolia in lakes, streams, rivers, canals, and even estuaries and brackish waters, up to $60 \mathrm{~m}$ in depth [27-29]. Its distribution is favored by rapid currents, high content of calcium, carbon dioxide, dissolved oxygen, and high conductivity [28-30]. Theodoxus fluviatilis is a scraper that feeds on biofilms, ingesting mainly diatoms, but it also feeds on cyanobacteria and detritus [27,29]. In rivers, $T$. fluviatilis is mainly fixed to the 
substrate - preferably stones where they scrap food-in shallow areas, and is less present in vegetation [27,30]. According to Graça et al. [30], the density of T. fluviatilis in the spring source of the Anços River (Portugal) can vary from approximately 10 individuals $/ \mathrm{m}^{2}$ to 9000 individuals $/ \mathrm{m}^{2}$, but decreases to zero $3800 \mathrm{~m}$ downstream. In the littoral zone of Lake Esrom (Denmark), a local population showed a variable density, between 556 individuals $/ \mathrm{m}^{2}$ and 2100 individuals $/ \mathrm{m}^{2}$, with a mean annual abundance of 1084 individuals $/ \mathrm{m}^{2}$ [29].

The present study aimed at developing a short-term laboratory and in situ assay based on the postexposure feeding of the freshwater snail T. fluviatilis. Four specific objectives were delineated. First, to develop a method to easily, precisely, and rapidly quantify feeding rates, while preventing organisms' physiological recovery. Second, to compare the sensitivity to cadmium of feeding and survival. Third, to determine the influence of abiotic conditions other than contamination on feeding rates. Fourth, to evaluate the effectiveness of the in situ assay by deploying it at contaminated sites.

\section{MATERIALS AND METHODS}

\section{Assay organisms}

Organisms of $T$. fluviatilis were collected at the spring source of the Anços River (Central Portugal: $39^{\circ} 58^{\prime} 43.40^{\prime \prime} \mathrm{N}$, $\left.8^{\circ} 34^{\prime} 23.30^{\prime \prime} \mathrm{W}\right)$, with a mean ( \pm standard error) annual water temperature of $16.1{ }^{\circ} \mathrm{C}\left( \pm 0.1{ }^{\circ} \mathrm{C}\right)$ [30]. This site was previously classified as minimally disturbed, based 1) on classes of water quality for multiple uses by the National Water Agency (INAG, Portugal), 2) on species composition and abundance in the riparian corridor, 3) on channel morphology, and 4) on urbanization and industrial activities in the catchment area [31]. It is presently considered as being in a good ecological status for support of aquatic life under the national implementation of the Water Framework Directive (M.J. Feio, Department of Life Sciences, University of Coimbra, Portugal).

Organisms were handpicked from streambed stones and transported in thermally insulated boxes filled with local water to the laboratory or directly to the in situ assay sites. For experiments on feeding quantification and endpoint sensitivity, organisms were conditioned for transportation (30-min trip) in plastic containers (length $\times$ width $\times$ height of $21 \mathrm{~cm} \times$ $15.4 \mathrm{~cm} \times 9.4 \mathrm{~cm})$. In the laboratory, cultures were maintained in a temperature controlled room at $19{ }^{\circ} \mathrm{C}$ to $21{ }^{\circ} \mathrm{C}$, under a 14-h:10-h light:dark light regime, in plastic containers with aerated culture medium ( $\sim 5 \mathrm{~cm}$ high) and local stones. Culture medium consisted initially of $100 \%$ local water and within the first week was gradually changed to $100 \%$ ASTM reconstituted hard water [32], hereafter referred to as ASTM medium. It was renewed 3 times a week, and the plastic containers were renewed once a week. Each collected batch of organisms was maintained under these controlled laboratory conditions during a maximum period of $2 \mathrm{wk}$. For the in situ experiments and assays, organisms were collected on the same day as deployment and conditioned to be transported to the study sites in 50-mL polypropylene vials (10 organisms/vial) filled with local water. The size of each experimental batch of organisms was estimated at the end of each experiment by measuring shell height and length in a sample of 20 organisms [27].

\section{In situ assay chambers and procedures}

Assay chambers were previously developed by Moreira et al. [7], each consisting of a 20-cm-long, 5-cm inner diameter, and $0.5-\mathrm{cm}$ wall thick acrylic tube with open ends and $1-\mathrm{cm}$ slimmed bottom edge to facilitate penetration into the sediment. The exchange of surrounding water (at the water-column level) and porewater (at the sediment level), between the interior and exterior of the chamber, was guaranteed by 2 opposite rectangular windows $(4 \mathrm{~cm} \times 10 \mathrm{~cm})$ covered with a $200-\mu \mathrm{m}$ nylon mesh. To cover the top end of the assay chamber during exposure, a $200-\mu \mathrm{m}$ nylon mesh $(15 \mathrm{~cm} \times 15 \mathrm{~cm})$, held by an elastic band, was used.

Assay chambers were carefully pushed into the sediment to a depth of approximately $10 \mathrm{~cm}$ so that lateral windows allowed the flow of both the overlying water, at the water-column level, and of porewater, at the sediment level. When needed, a holding structure made from a basket of plastic coated metal wire $(10 \mathrm{~cm} \times 21 \mathrm{~cm} \times 25 \mathrm{~cm})$ was used to protect assay chambers from strong water flows [16]. Three replicate chambers were deployed at each site and 10 organisms were deployed per chamber. Although only 8 organisms were required to quantify postexposure feeding rates, the deployment of 10 organisms per chamber, while respecting field densities [29,30], facilitated organism retrieval at the end of the assay. After the 48-h exposure period, chambers were retrieved and individually placed into trays to retrieve the organisms from the sediment. Organisms from each replicate were placed into the same $50-\mathrm{mL}$ polypropylene used for transportation to the field sites filled with local water to prevent organisms' physiological recovery, and transported to the laboratory inside thermally insulated boxes at approximately $20{ }^{\circ} \mathrm{C}$. A 5 -h period from retrieval of the chambers until the beginning of the postexposure feeding quantification was established to provide similar conditions among sites. Individuals were allowed to feed according to the procedures described below.

Conductivity (Wissenschaftlich Technische Werkstatten [WTW] Cond315i/SET conductivity meter), temperature (WTW Cond315i/SET), dissolved oxygen (WTW OXI 92 oxygen meter), pH (WTW 537 pH meter), and current velocity (Valeport 108 MkIII current meter) were measured at deployment and at retrieval, at each site. Water samples were collected at each site and kept frozen until hardness and metal analysis. Total hardness was determined by spectrophotometry (method 2340 B [33]), using a DR 3900 equipment (HACH LANGE). At each site, composite sediment samples were collected into black airtight plastic bags, transported to the laboratory, and stored at $4{ }^{\circ} \mathrm{C}$ until processed for analysis. Sediment water content was determined by measuring the loss of weight of 3 subreplicates after oven drying at $60{ }^{\circ} \mathrm{C}$ for $3 \mathrm{~d}$. Sediment organic matter content (percentage of volatile solids) was determined by quantifying the loss of weight after ignition in a muffle furnace (Nabatherm L3) at $600{ }^{\circ} \mathrm{C}$ for $6 \mathrm{~h}$ [34]. Sediment particle size distribution was analyzed by sieving the sediment (pooling of 3 subreplicates) into 11 fractions, ranging from $63 \mu \mathrm{m}$ to $64 \mathrm{~mm}$ [34].

\section{Study sites}

To evaluate the effect on postexposure feeding of the environmental abiotic conditions, other than contamination, and the effectiveness of the in situ assay, 5 reference sites [35] (R1R5) were selected within the Mondego River basin (Central Portugal) and 1 reference (R6) and 5 sites impacted by an acid mine effluent in the Água Forte stream [36] (I1-I5), within the Sado River basin (South Portugal; Tables 1 and 2).

\section{Feeding quantification}

To develop a methodology to precisely quantify $T$. fluviatilis postexposure feeding rates in the shortest possible period, 
Table 1. Local names, geographical coordinates, sediment water and organic matter contents (in $\%$; \pm standard deviation inside parentheses), and sediment particle size distribution (in \%) of the reference sites (R1-R6) where in situ experiments and assays based on postexposure feeding of the freshwater snail Theodoxus fluviatilis were deployed

\begin{tabular}{|c|c|c|c|c|c|c|c|}
\hline & R1 sand & R1 gravel & $\mathrm{R} 2$ & R3 & $\mathrm{R} 4$ & R5 & R6 \\
\hline Name & Anços River & Anços River & Anços River & Arunca River & Crespos stream & São João stream & Roxo River \\
\hline \multicolumn{8}{|l|}{ Coordinates } \\
\hline Latitude & $39^{\circ} 58^{\prime} 43.40^{\prime \prime} \mathrm{N}$ & $39^{\circ} 58^{\prime} 43.40^{\prime \prime} \mathrm{N}$ & $39^{\circ} 59^{\prime} 53.45^{\prime \prime} \mathrm{N}$ & $39^{\circ} 52^{\prime} 53.00^{\prime \prime} \mathrm{N}$ & $39^{\circ} 54^{\prime} 28.45^{\prime \prime} \mathrm{N}$ & $40^{\circ} 05^{\prime} 58.50^{\prime \prime} \mathrm{N}$ & $37^{\circ} 56^{\prime} 29.60^{\prime \prime} \mathrm{N}$ \\
\hline Longitude & $8^{\circ} 34^{\prime} 23.30^{\prime \prime} \mathrm{W}$ & $8^{\circ} 34^{\prime} 23.30^{\prime \prime} \mathrm{W}$ & $8^{\circ} 35^{\prime} 02.15^{\prime \prime} \mathrm{W}$ & $8^{\circ} 37^{\prime} 12.65^{\prime \prime} \mathrm{W}$ & $8^{\circ} 42^{\prime} 18.00^{\prime \prime} \mathrm{W}$ & $8^{\circ} 14^{\prime} 02.60^{\prime \prime} \mathrm{W}$ & $8^{\circ} 08^{\prime} 04.30^{\prime \prime} \mathrm{W}$ \\
\hline \multicolumn{8}{|l|}{ Sediment } \\
\hline Water content & $6.55( \pm 0.95)$ & $18.0( \pm 0.46)$ & $23.1( \pm 0.56)$ & $60.8( \pm 1.3)$ & $17.8( \pm 0.18)$ & $7.59( \pm 0.65)$ & $17.5( \pm 1.0)$ \\
\hline OM content & $0.81( \pm 0.72)$ & $0.26( \pm 0.10)$ & $1.4( \pm 0.28)$ & $9.0( \pm 1.2)$ & $0.57( \pm 0.034)$ & $1.1( \pm 0.047)$ & $1.9( \pm 0.11)$ \\
\hline \multicolumn{8}{|l|}{ Particle size } \\
\hline $32-64 \mathrm{~mm}$ & 22.9 & 0.00 & 0.00 & 0.00 & 0.00 & 2.00 & 0.00 \\
\hline $16-32 \mathrm{~mm}$ & 3.50 & 0.00 & 0.372 & 0.00 & 0.664 & 26.8 & 0.00 \\
\hline $8-16 \mathrm{~mm}$ & 33.3 & 0.00 & 0.954 & 0.00 & 0.928 & 42.9 & 0.00 \\
\hline $4-8 \mathrm{~mm}$ & 18.1 & 0.166 & 3.24 & 0.00 & 0.685 & 20.4 & 10.4 \\
\hline $2-4 \mathrm{~mm}$ & 11.5 & 1.61 & 11.1 & 6.59 & 1.74 & 5.25 & 24.2 \\
\hline $1-2 \mathrm{~mm}$ & 4.93 & 17.5 & 31.5 & 12.4 & 5.99 & 2.36 & 23.9 \\
\hline $0.5-1 \mathrm{~mm}$ & 3.26 & 35.8 & 22.2 & 12.2 & 19.9 & 0.142 & 21.3 \\
\hline $250-500 \mu \mathrm{m}$ & 2.01 & 36.0 & 16.4 & 13.6 & 26.7 & 0.0364 & 11.6 \\
\hline $125-250 \mu \mathrm{m}$ & 0.285 & 8.37 & 10.1 & 27.3 & 26.7 & 0.0245 & 5.69 \\
\hline $63-125 \mu \mathrm{m}$ & 0.0915 & 0.336 & 2.62 & 14.2 & 16.3 & 0.0206 & 1.98 \\
\hline$<63 \mu \mathrm{m}$ & 0.138 & 0.145 & 1.44 & 13.7 & 0.434 & 0.0705 & 0.988 \\
\hline
\end{tabular}

$\mathrm{OM}=$ organic matter.

Table 2. Geographical coordinates, sediment water and organic matter contents (in \%; \pm standard deviation inside parentheses), and sediment particle size distribution (in \%) of the sites impacted with acid mine drainage in Água Forte stream (I1-I5) where the in situ assay based on postexposure feeding of the freshwater snail Theodoxus fluviatilis was deployed

\begin{tabular}{|c|c|c|c|c|c|}
\hline & I1 & $\mathrm{I} 2$ & $\mathrm{I} 3$ & I4 & I5 \\
\hline \multicolumn{6}{|l|}{ Coordinates } \\
\hline Latitude & $37^{\circ} 56^{\prime} 31.10^{\prime \prime} \mathrm{N}$ & $37^{\circ} 56^{\prime} 39.05^{\prime \prime} \mathrm{N}$ & $37^{\circ} 56^{\prime} 41.00^{\prime \prime} \mathrm{N}$ & $37^{\circ} 56^{\prime} 42.70^{\prime \prime} \mathrm{N}$ & $37^{\circ} 56^{\prime} 43.20^{\prime \prime} \mathrm{N}$ \\
\hline Longitude & $8^{\circ} 08^{\prime} 53.35^{\prime \prime} \mathrm{W}$ & $8^{\circ} 09^{\prime} 01.05^{\prime \prime} \mathrm{W}$ & $8^{\circ} 09^{\prime} 01.90^{\prime \prime} \mathrm{W}$ & $8^{\circ} 09^{\prime} 01.85^{\prime \prime} \mathrm{W}$ & $8^{\circ} 09^{\prime} 02.06^{\prime \prime} \mathrm{W}$ \\
\hline \multicolumn{6}{|l|}{ Sediment } \\
\hline Water content & $14.0( \pm 1.2)$ & $24.3( \pm 0.14)$ & $61.6( \pm 0.92)$ & $59.3( \pm 0.57)$ & $32.5( \pm 0.87)$ \\
\hline OM content & $3.1( \pm 0.42)$ & $4.6( \pm 0.44)$ & $11( \pm 0.45)$ & $11( \pm 1.1)$ & $4.3( \pm 0.19)$ \\
\hline \multicolumn{6}{|l|}{ Particle size } \\
\hline $32-64 \mathrm{~mm}$ & 0.00 & 0.00 & 0.00 & 0.00 & 0.00 \\
\hline $16-32 \mathrm{~mm}$ & 0.00 & 9.67 & 0.00 & 0.00 & 0.00 \\
\hline $8-16 \mathrm{~mm}$ & 0.00 & 5.82 & 2.98 & 6.55 & 4.19 \\
\hline $4-8 \mathrm{~mm}$ & 15.7 & 4.40 & 13.1 & 2.94 & 6.02 \\
\hline $2-4 \mathrm{~mm}$ & 2.40 & 8.53 & 19.1 & 10.1 & 19.8 \\
\hline $1-2 \mathrm{~mm}$ & 10.5 & 25.1 & 17.8 & 13.8 & 12.3 \\
\hline $0.5-1 \mathrm{~mm}$ & 44.6 & 23.8 & 12.5 & 14.8 & 20.2 \\
\hline $250-500 \mu \mathrm{m}$ & 23.6 & 12.3 & 2.31 & 23.5 & 17.7 \\
\hline $125-250 \mu \mathrm{m}$ & 2.28 & 5.58 & 17.2 & 14.0 & 11.7 \\
\hline $63-125 \mu \mathrm{m}$ & 0.190 & 2.47 & 2.22 & 7.87 & 4.75 \\
\hline$<63 \mu \mathrm{m}$ & 0.345 & 2.33 & 12.8 & 6.51 & 3.37 \\
\hline
\end{tabular}

$\mathrm{OM}=$ organic matter.

aiming at minimizing organisms' physiological recovery, experiments were conducted with organisms deprived of food during the previous $24 \mathrm{~h}$. Dried spinach mats and defrosted nauplii (less than 24 h-old) of the brine shrimp Artemia franciscana were the 2 food types preliminarily tested. Whereas spinach was selected because snails are grazers, Artemia sp. nauplius was selected based on previous studies showing its suitability to rapidly quantify feeding rates [16,19] and also because the nauplii are easy to obtain, handle, and quantify without the need for laboratory cultures or laborious weight measurements. Dried spinach mats were prepared according to Crichton et al. [12]. In brief, frozen spinach (Iglo) was macerated with a hand blender using ASTM medium $(1 \mathrm{~g} / \mathrm{mL})$ for $2 \mathrm{~min}$, and $5 \mathrm{~mL}$ of this mixture were used to fill the bottom of 8-cm-diameter plastic Petri dishes, which were left to dry at $60{ }^{\circ} \mathrm{C}$ overnight. To quantify feeding rates on dried spinach mats, egestion was used as a surrogate of feeding according to Krell et al. [13]. In short, a 3-stage procedure at $20{ }^{\circ} \mathrm{C}$ in darkness was followed: 1) a first stage of $60 \mathrm{~min}, 90 \mathrm{~min}$, $120 \mathrm{~min}$, or $180 \mathrm{~min}$ for organisms to clean their guts in ASTM medium; 2) a second stage of $1 \mathrm{~h}$ to allow organisms to feed on spinach; and 3) a third stage of $60 \mathrm{~min}, 90 \mathrm{~min}$, or $120 \mathrm{~min}$ to allow organisms to egest. A minimal consumption of spinach and a high variability in the number of fecal pellets, being hard to individualize, were found.

Nauplii of A. franciscana were obtained by incubating cysts (Creasel) in standard reconstituted seawater (salinity of 35 and $\mathrm{pH}$ of 7.6 ), at $24{ }^{\circ} \mathrm{C}$ to $26{ }^{\circ} \mathrm{C}$ under continuous light $\left(75 \mu \mathrm{E} / \mathrm{m}^{2} / \mathrm{s}\right.$ ) for $24 \mathrm{~h}$; they were then stored in $1.5-\mathrm{mL}$ Eppendorf tubes with ASTM medium at $-20{ }^{\circ} \mathrm{C}$, for up to 2 mo [16]. Preliminary experiments were conducted with different combinations of vial shape and ASTM medium volume 
(30-mL, 2.2-cm-diameter glass vials with $5 \mathrm{~mL}$ medium and 24-well microplates with $1 \mathrm{~mL}$ medium per well), organism density (1, 3, and 5), food quantity (100 nauplii and 150 nauplii), and feeding periods ( $1 \mathrm{~h}$ up to $3 \mathrm{~h}$ ). Nauplii were actively consumed by $T$. fluviatilis and were thus a suitable food to quantify feeding. A further preliminary experiment to investigate the influence of food quantity (100 nauplii vs 150 nauplii) was performed. For each treatment, 20 replicates were set up in 24-well microplates with each replicate consisting of 1 organism/well filled with $1 \mathrm{~mL}$ ASTM medium. Organisms were allowed to feed for $3 \mathrm{~h}$ in darkness. Organisms had mean ( \pm standard deviation $[\mathrm{SD}] ; n=20$ ) shell height and length of $4.39 \mathrm{~mm}( \pm 0.24 \mathrm{~mm})$ and $5.56 \mathrm{~mm}( \pm 0.25 \mathrm{~mm})$, respectively. Snails ate more when 150 nauplii rather than 100 nauplii were available (13 nauplii/organism/3 h and 22 nauplii/organism/3 h, respectively; Student's $t$ test: $t_{35}=2.96 ; p<0.01$ ), with no differences between coefficient of variation $(C V)$ values $(49 \%$ and $46 \%$, respectively; $Z=0.216 ; p>0.05)$. Therefore, snails placed individually in each well of 24-well microplates containing $1 \mathrm{~mL}$ of ASTM medium and 150 defrosted nauplii and allowed to feed in darkness for $3 \mathrm{~h}$, was the adopted definitive methodology.

A definitive experiment was further conducted to evaluate whether the time lag between organism collection and feeding quantification, that is, laboratory culture age ( $1 \mathrm{~d}$ up to $7 \mathrm{~d}$ ), influenced $T$. fluviatilis feeding rate. For $7 \mathrm{~d}$ in a row, starting the day after organism collection, 20 replicate organisms, with an overall mean ( $\pm \mathrm{SD} ; n=140)$ shell height and length of $4.02 \mathrm{~mm}( \pm 0.22 \mathrm{~mm})$ and $5.05 \mathrm{~mm}( \pm 0.22 \mathrm{~mm})$, were collected daily from cultures and allowed to feed under the above stated conditions. The influence of organism size on feeding rate was tested twice using 20 individuals from 2 size classes, with overall means ( \pm SD) of shell height and length of $4.08 \mathrm{~mm}( \pm 0.24 \mathrm{~mm})$ and $5.12 \mathrm{~mm}( \pm 0.19 \mathrm{~mm} ; n=40)$ and of $4.86 \mathrm{~mm}( \pm 0.22 \mathrm{~mm})$ and $6.12 \mathrm{~mm}( \pm 0.33 \mathrm{~mm} ; n=40)$, respectively.

\section{Endpoint sensitivity}

The 48-h postexposure feeding median effective concentration (EC50) of cadmium was compared with the 48-h and 96-h median lethal concentration (LC50). A stock solution of cadmium $(5 \mathrm{~g} / \mathrm{L})$ prepared in nanopure water with cadmium chloride monohydrate (Merck) was used to prepare 7 test solutions by adding the appropriate volumes to ASTM medium, with a dilution factor of $1.5(750 \mu \mathrm{g} / \mathrm{L}, 500 \mu \mathrm{g} / \mathrm{L}, 333 \mu \mathrm{g} / \mathrm{L}$, $222 \mu \mathrm{g} / \mathrm{L}, 148 \mu \mathrm{g} / \mathrm{L}, 98.8 \mu \mathrm{g} / \mathrm{L}$, and $65.8 \mu \mathrm{g} / \mathrm{L})$. Two tests were carried out differing in exposure duration, $48 \mathrm{~h}$ and $96 \mathrm{~h}$. The mean ( $\pm \mathrm{SD} ; n=20$ ) shell height and length of the organisms used in the 96 -h test were $4.25 \mathrm{~mm}( \pm 0.21 \mathrm{~mm})$ and $5.37 \mathrm{~mm}( \pm 0.21 \mathrm{~mm})$, and the corresponding means of those used in the 48 -h test were $4.32 \mathrm{~mm}( \pm 0.23 \mathrm{~mm})$ and $5.38 \mathrm{~mm}$ $( \pm 0.24 \mathrm{~mm})$. For both tests, 5 replicates were set up. Each replicate consisted of 5 organisms in a $60-\mathrm{mL}$ glass vial filled with test solution, covered with a $200-\mu \mathrm{m}$ nylon mesh, held in place with an elastic band, and placed inside 5-cm-diameter polyethylene terephthalate containers filled with the test solution, so that the vials were submerged to guarantee continuous exposure. Tests were conducted at $19{ }^{\circ} \mathrm{C}$ to $21{ }^{\circ} \mathrm{C}$ under a 14 $\mathrm{h}: 10-\mathrm{h}$ light:dark light regime, without food. In the 96-h test, solutions were renewed once at $48 \mathrm{~h}$. Mortality was verified by touching the organisms with a needle; snails not reacting were considered dead. Feeding was quantified immediately at the end of exposure and only after mortality was assessed to prevent inducing extra stress. Conductivity, dissolved oxygen, and $\mathrm{pH}$ were measured in 2 replicates of all fresh and old test solutions. Actual cadmium concentrations were quantified by atomic absorption gas chromatography (method 3113 B [33]) and by inductively coupled plasma (method 3120 [33]), in a certified laboratory (Instituto Superior Técnico, Lisbon, Portugal). The actual cadmium concentration of the stock solution matched the nominal value $(5 \mathrm{~g} / \mathrm{L})$. The solutions of $500 \mu \mathrm{g} / \mathrm{L}, 333 \mu \mathrm{g} / \mathrm{L}$, $222 \mu \mathrm{g} / \mathrm{L}, 148 \mu \mathrm{g} / \mathrm{L}, 98.8 \mu \mathrm{g} / \mathrm{L}$, and $65.8 \mu \mathrm{g} / \mathrm{L}$ represented actual concentrations in fresh and 48-h-old solutions (maximum period without medium renewal) of $480 \mu \mathrm{g} / \mathrm{L}, 340 \mu \mathrm{g} / \mathrm{L}$, $210 \mu \mathrm{g} / \mathrm{L}, 140 \mu \mathrm{g} / \mathrm{L}, 90 \mu \mathrm{g} / \mathrm{L}$, and $62 \mu \mathrm{g} / \mathrm{L}$; and $230 \mu \mathrm{g} / \mathrm{L}$, $69 \mu \mathrm{g} / \mathrm{L}, 80 \mu \mathrm{g} / \mathrm{L}, 25 \mu \mathrm{g} / \mathrm{L}$, and $8 \mu \mathrm{g} / \mathrm{L}$, respectively. Toxicity estimates were computed with the geometric means of actual concentrations.

\section{Influence of exposure conditions on postexposure feeding}

The influence of environmental abiotic conditions, other than contamination, on the background variability of postexposure feeding rates was investigated with an experiment consisting of 9 in situ exposures at reference sites R1 to R5, covering a broad range of current velocity, hardness, conductivity, sediment organic matter content, and sediment particle size distribution (Tables 1 and 3). The organisms' mean ( $\pm \mathrm{SD} ; n=20)$ shell height and length were $4.23 \mathrm{~mm}( \pm 0.13 \mathrm{~mm})$ and $5.28 \mathrm{~mm}$ $( \pm 0.14 \mathrm{~mm})$. Further evidence of the influence of environmental conditions, including temperature, was gathered in an ulterior in situ experiment at R1, R2, and R6 (Tables 1 and 3). The mean ( $\pm \mathrm{SD} ; n=20$ ) shell height and length of the organisms used in this experiment were $4.40 \mathrm{~mm}( \pm 0.15 \mathrm{~mm})$ and $5.44 \mathrm{~mm}$ $( \pm 0.14 \mathrm{~mm})$.

\section{Postexposure feeding assay with contaminated natural waters}

The effectiveness of the postexposure feeding assay was evaluated through in situ exposures at R6 and at I1 to I5 (Tables 1-3). This assay was simultaneous and used the same batch of organisms as the second experiment on the influence of abiotic conditions at sites R1, R2, and R6. Metal concentrations at sites R6, I1, I4, and I5 were quantified, in a certified laboratory (Instituto Superior Técnico), by inductively coupled plasma (method 3120 [33]), by atomic absorption gas chromatography (method 3113 B [33]) and by atomic absorption spectroscopy with hydrid generation (for the arsenic; method M.M. 5.2 [33]). Intermediate contaminated sites I 2 and I 3 were not subjected to metal analysis because, like I1 and I4, they were fully lethal.

\section{Data analysis}

In the 7-d experiment on the influence of culture age, 2 oneway analysis of variance (ANOVA) tests (for shell height and length) confirmed that all sets of 20 organisms used daily had a similar size $\left(F_{6,133}<0.92 ; p>0.30\right)$, and a subsequent oneway ANOVA was used to compare feeding rates among culture ages. In the experiment on the influence of organism size, Student's $t$ tests confirmed that shell height and length between the 2 size classes were different $\left(t_{78}>15 ; p<0.001\right)$. Differences in feeding rates between repetitions and size classes were tested with a two-way mixed-model ANOVA, with repetition as a random-effects factor [37]. The associations between individual feeding rate and shell size were assessed with Pearson's correlation coefficient. Assumptions of normality and homoscedasticity were checked with Shapiro-Wilk's and Bartlett's tests, respectively.

The 48- and 96-h LC20 and LC50 of cadmium and the respective $95 \%$ confidence limits $(95 \% \mathrm{CL})$ were calculated using the software PriProbit 1.63 (http://ars.usda.gov/Services/ 
Table 3. Temperature (range, minimum-maximum), current velocity, conductivity (range, minimum-maximum at impacted sites), dissolved oxygen, hardness, and $\mathrm{pH}$ during in situ experiments and assays based on postexposure feeding of the freshwater snail Theodoxus fluviatilis at reference (R1-R6) and impacted sites contaminated with acid mine drainage (I1-I5)

\begin{tabular}{|c|c|c|c|c|c|c|}
\hline Site & Temperature $\left({ }^{\circ} \mathrm{C}\right)$ & Current velocity (m/s) & Conductivity $(\mu \mathrm{S} / \mathrm{cm})$ & DO $(\mathrm{mg} / \mathrm{L})$ & Hardness $\left(\mathrm{mg} \mathrm{CaCO}_{3} / \mathrm{L}\right)$ & $\mathrm{pH}$ \\
\hline $\mathrm{R} 1$ gravel fast & $16.3-16.6$ & 0.60 & 550 & 9.60 & 129.1 & 7.1 \\
\hline $\mathrm{R} 1$ sand fast & $16.3-16.6$ & 0.60 & 550 & 9.60 & 129.1 & 7.1 \\
\hline $\mathrm{R} 1$ gravel slow & $16.3-16.6$ & $<0.01$ & 550 & 9.60 & 129.1 & 7.1 \\
\hline $\mathrm{R} 1$ sand slow ${ }^{\mathrm{a}}$ & $16.3-16.6$ & $<0.01$ & 550 & 9.60 & 129.1 & 7.1 \\
\hline $\mathrm{R} 2^{\mathrm{a}}$ & $16.4-17.0$ & $<0.01$ & 528 & 10.3 & 129.1 & 7.8 \\
\hline R3 & $15.5-17.3$ & 0.02 & 668 & 10.3 & 117.3 & 7.9 \\
\hline R4 & $15.9-17.2$ & 0.25 & 175 & 9.60 & 47.14 & 7.1 \\
\hline R5 fast & $14.4-16.1$ & 0.20 & 45.7 & 13.2 & 11.25 & 7.1 \\
\hline R5 slow & $14.4-16.1$ & $<0.01$ & 45.7 & 13.2 & 11.25 & 7.1 \\
\hline R1 sand slow ${ }^{b}$ & $16.7-18.7$ & 0.02 & 550 & 9.60 & $-\mathrm{c}$ & 7.1 \\
\hline $\mathrm{R} 2^{\mathrm{b}}$ & $18.2-21.3$ & $<0.01$ & 528 & 10.3 & - & 7.8 \\
\hline R6 & $20.3-20.7$ & $<0.01$ & 1240 & 3.60 & 352.0 & 7.5 \\
\hline I1 & $24.8-25.0$ & $<0.01$ & $4220-4260$ & 9.50 & 2,103 & 2.1 \\
\hline $\mathrm{I} 2$ & $22.3-23.8$ & $<0.01$ & $2480-3050$ & 17.7 & $-\mathrm{c}$ & 2.5 \\
\hline I3 & $23.5-24.2$ & $<0.01$ & $1735-2060$ & 12.0 & $\underline{-}^{\mathrm{c}}$ & 5.5 \\
\hline I4 & $23.1-24.1$ & $<0.01$ & $1345-1650$ & 10.0 & $-^{\mathrm{c}}$ & 7.0 \\
\hline I5 & $23.0-24.6$ & $<0.01$ & $1255-1540$ & 10.2 & 621.4 & 7.2 \\
\hline
\end{tabular}

${ }^{\mathrm{a}}$ Measured at the first in situ experiment.

${ }^{\mathrm{b}}$ Measured at the second in situ experiment.

${ }^{\mathrm{c}}$ Not measured.

$\mathrm{DO}=$ dissolved oxygen.

docs.htm?docid=11284), applying the probit transformation to mortality and the logarithmic transformation to concentration. The 48-h postexposure feeding $20 \%$ effective concentration (EC20) and EC50 and respective 95\% CLs were estimated by fitting a logistic model [38].

To integrate the effect of cadmium on survival and on individual feeding into a single parameter-the immediate inhibition of population consumption-2 methods were used $[10,32]$. First, the feeding rate at each concentration was multiplied by the respective proportional survival and a logistic model was fitted to estimate popEC $x$ values (i.e., concentrations causing $x \%$ inhibition in the immediate population consumption). Second, the concentration-response relationships of feeding and of survival were integrated as $x \%$ of the population consumption inhibition induced by the concentration that simultaneously caused a $y \%$ mortality (i.e., the LCy) and a $w$ $\%$ depression on feeding (i.e., the $\mathrm{EC} w$; therefore, $\mathrm{LC} y=\mathrm{EC} w$ ), $x$ (in \%) being quantified as $[13,19]$

$$
x=\left[1-\left(1-\frac{y}{100}\right) \times\left(1-\frac{w}{100}\right)\right] \times 100
$$

To quantify the influence of abiotic parameters on the postexposure feeding rate, a multiple linear regression analysis was performed with the data from the experiment at sites R1 to R5, using the software R 2.6.0 (http://cran.r-project.org/bin/ windows/base) and Brodgar 2.5.7 (Highland Statistics). Explanatory variables included in the model were current velocity, hardness, organic matter content, and percentage of sand (particle size between $0.063 \mathrm{~mm}$ and $2.0 \mathrm{~mm}$ ). Temperature and $\mathrm{pH}$ were not included in the model because their variation among sites was minimal. Conductivity and percentages of silt and gravel were excluded because of strong collinearity with hardness $(r=0.89)$, organic matter content $(r=0.99)$, and percentage of sand $(r=1.00)$, respectively. In the second experiment on the influence of abiotic conditions, feeding rates among the 3 reference sites (R1, R2, and R6) were tested with a one-way nested ANOVA. Feeding rates at I5 and R6 were also compared with a one-way nested ANOVA.

Except as otherwise stated, Statistica 7.0 (StatSoft) was used, with $F$ values being calculated according to Zar [30].

\section{RESULTS}

\section{Feeding quantification}

Culture age had no effect on feeding $\left(F_{6,127}=1.64\right.$; $p=0.14$ ), with daily means from 21 nauplii/organism/3 h to 29 nauplii/organism/3 h and $C V$ from $30 \%$ to $49 \%$. Neither size class, nor repetition, nor their interaction influenced feeding $(F<1.3 ; p>0.26)$. No significant correlations between feeding rate and either shell height $(r=0.09 ; p=0.22)$ or length $(r=0.11 ; p=0.14)$ were found.

\section{Endpoint sensitivity}

Dissolved oxygen was always above $40 \%$, and $\mathrm{pH}$ and conductivity ranged from 7.2 to 7.9 and $547 \mu \mathrm{S} / \mathrm{cm}$ to $595 \mu \mathrm{S} /$ $\mathrm{cm}$, respectively. In both 48 -h and 96 -h tests with cadmium, no control mortality occurred. The 48-h and 96-h LC50 values $(95 \%$ CL) were $102 \mu \mathrm{g} / \mathrm{L}(89-115 \mu \mathrm{g} / \mathrm{L})$ and $64 \mu \mathrm{g} / \mathrm{L}(54-76 \mu \mathrm{g} / \mathrm{L})$, respectively, whereas LC20 values were $77 \mu \mathrm{g} / \mathrm{L}(63-89 \mu \mathrm{g} / \mathrm{L})$ and $38 \mu \mathrm{g} / \mathrm{L}(28-46 \mu \mathrm{g} / \mathrm{L})$, respectively. The $48-\mathrm{h}$ postexposure feeding EC50 and EC20 values were $85 \mu \mathrm{g} / \mathrm{L}(64-106 \mu \mathrm{g} / \mathrm{L})$ and $41 \mu \mathrm{g} / \mathrm{L}(23-58 \mu \mathrm{g} / \mathrm{L})$, respectively. Figure 1 presents detailed results of the observed percentages of mortality and individual feeding inhibition in the 48-h tests with cadmium and the respective mortality, individual feeding, and population consumption (using the first integration technique, as both techniques led to similar results) models. As expected, individual feeding started to be inhibited at concentrations well below those causing mortality, whereas the population consumption was inhibited at cadmium concentrations below those inhibiting individual feeding only for cadmium lethal concentrations. The first integration technique led to 48 -h population consumption EC20 and EC50 estimates of $45 \mu \mathrm{g} / \mathrm{L}(35-55 \mu \mathrm{g} / \mathrm{L})$ and $69 \mu \mathrm{g} / \mathrm{L}$ $(58-79 \mu \mathrm{g} / \mathrm{L})$, respectively, whereas the second integration technique led to an EC50 estimate of $71 \mu \mathrm{g} / \mathrm{L}$, resulting from $14 \%$ mortality and $42 \%$ individual feeding depression; the popEC20 with the latter technique was considered to be equal to the individual EC20 because it occurred at concentrations below that of the LC1 (i.e., for cadmium concentrations with mortality well below 1\%). The second technique also indicated that at the 48-h feeding, EC50 (85 $\mu \mathrm{g} / \mathrm{L})$, mortality would be $30 \%$ and 


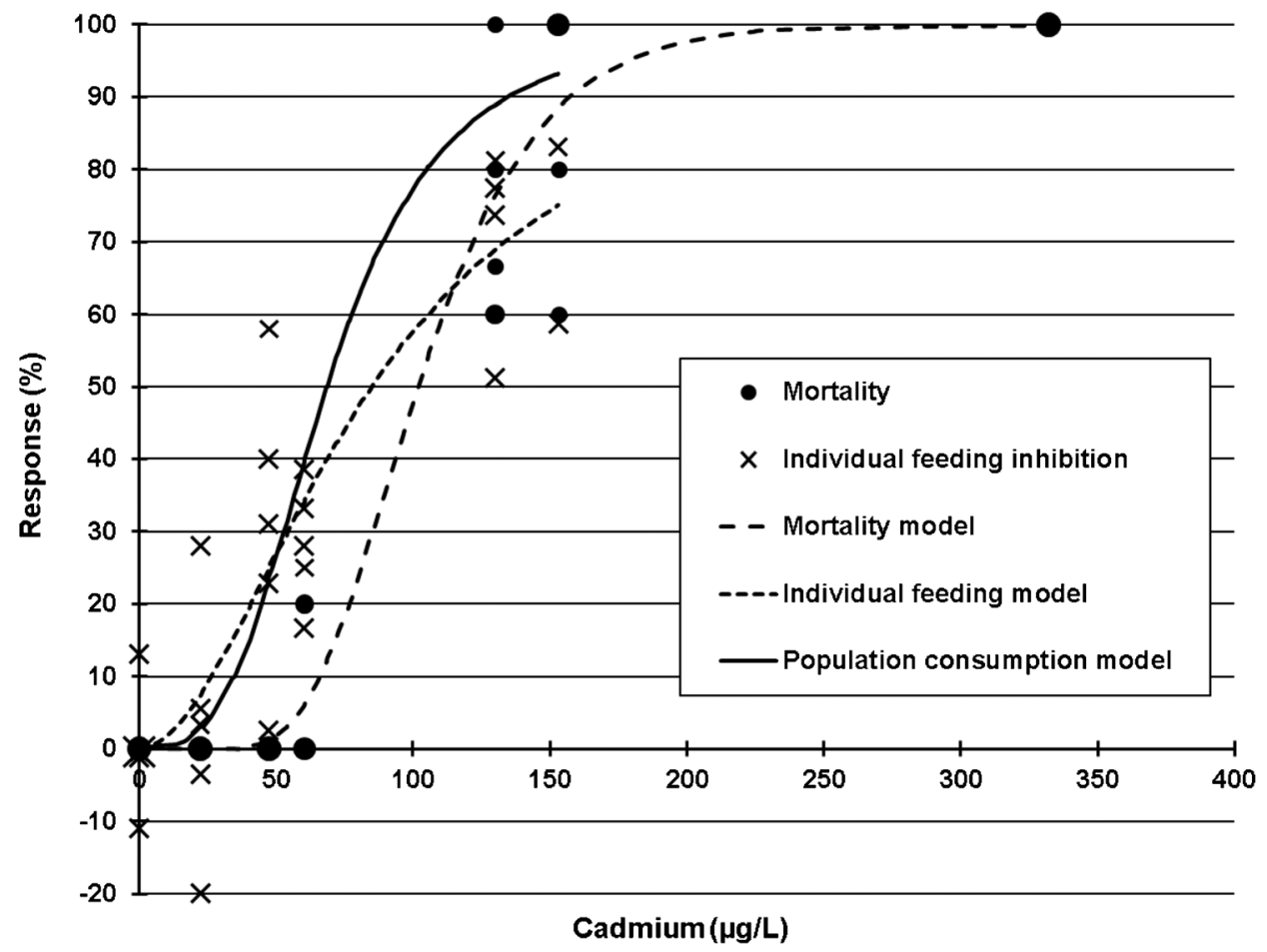

Figure 1. Observed mortality ( $\% ; n=5 /$ concentration) and individual feeding inhibition ( $\% ; n=5 /$ concentration) of Theodoxus fluviatilis exposed to a gradient of cadmium concentrations for $48 \mathrm{~h}$, and respective mortality, individual feeding, and population consumption models.

population consumption would be depressed by $65 \%$. At the $48-\mathrm{h}$ LC20 (77 $\mu \mathrm{g} / \mathrm{L})$, individual feeding and population consumption would be depressed by $45 \%$ and $56 \%$, respectively, whereas at the 48-h LC50 (102 $\mu \mathrm{g} / \mathrm{L})$, they would be depressed by $58 \%$ and $79 \%$, respectively.

\section{Influence of exposure conditions on postexposure feeding}

Organisms were easily retrieved from the chambers, and no mortalities were recorded. No environmental parameter influenced feeding rates of organisms deployed in the first experiment, at sites R1 to R5 ( $p>0.15$ ). A similar result was found in the second experiment, at sites R1, R2, and R6 $\left(F_{2,56}=2.02 ; p=0.21\right)$.

\section{Postexposure feeding assay with contaminated natural waters}

Metal concentrations at R6, I1, I4, and I5 are presented in Table 4. Mortality occurred at all impacted sites, being $100 \%$ at I1 to I 4 and $37 \%$ at I5. Feeding at I5 was inhibited by $46 \%$ relative to the reference site R6 $\left(F_{1,24}=22.7 ; p<0.001\right)$, with means $( \pm \mathrm{SD})$ of 20.7 nauplii/organism/3 h ( \pm 12 nauplii/ organism/3 h) and 44.9 nauplii/organism/3 h ( \pm 14 nauplii/ organism/3 h), respectively. Population consumption would be inhibited by $71 \%$.

\section{DISCUSSION}

\section{Feeding quantification}

The establishment of procedures to precisely quantify feeding rates was the first specific objective toward the development of a short-term sublethal laboratory and in situ toxicity assay based on the postexposure feeding of the freshwater snail $T$. fluviatilis. Ideally, feeding rates ought to be measured during exposure to avoid a possible physiological recovery of the organisms after exposure. However, because it is difficult to quantify feeding during exposure, particularly during in situ testing, the use of postexposure feeding has been widely acknowledged as a valid approach because toxic effects generally persist in the period immediately after toxicant exposure $[6,12]$. In the present study, a postexposure feeding period of $3 \mathrm{~h}$ was established, being a compromise between precision and a possible physiological recovery. Shorter periods have been proposed for other organisms, namely, 30 min for an amphipod [19] and $1 \mathrm{~h}$ for a midge [16]. Physiological recovery by the cladoceran Daphnia magna was found to occur approximately $4 \mathrm{~h}$ after exposures to sublethal concentrations of copper, fluoranthene [6], and phenol [39]. Brent and Herricks [39] reported the freshwater amphipod Hyalella azteca to be unable to recover its mobility $7 \mathrm{~d}$ after 10-d exposures to cadmium and zinc.

Up to the present, to our knowledge, all toxicity tests with snails based on feeding used egestion as a surrogate either with spinach mats (the freshwater snail Lymnaea peregra [12]) or sediment as food (the estuarine mudsnail Hydrobia ulvae $[13,40])$. In the present study, preliminary attempts to quantify egestion after a feeding period on spinach mats were first carried out. However, spinach consumption was minimal, individual fecal pellets were difficult to quantify, and a high variability in fecal pellets production was found. Preliminary attempts revealed that defrosted nauplii of $A$. fransciscana were readily consumed and were thus suitable food. Using nauplii greatly simplified and speeded up feeding quantification, yielding more precise results. Preliminary experiments showed T. fluviatilis to eat significantly more when 150 rather than 100 nauplii were provided. This was an expected result because the probability of a snail finding a nauplius increases with food density, as has been observed previously with the midge Chironomus riparius [16].

In the experiment on the influence of laboratory culture age (up to $7 \mathrm{~d}$ ) on the feeding rate of $T$. fluviatilis, no differences were detected, indicating that culture procedures are suitable to 
Table 4. Metal concentrations during in situ assays based on postexposure feeding of the freshwater snail Theodoxus fluviatilis at reference (R6) and impacted sites contaminated with acid mine drainage, both fully (I1 and I4) and partially lethal (I5)

\begin{tabular}{lcccccccccccc}
\hline & $\mathrm{Al}$ & $\mathrm{As}$ & $\mathrm{Cd}$ & $\mathrm{Co}$ & $\mathrm{Cu}$ & $\mathrm{Fe}$ & $\mathrm{Mn}$ & $\mathrm{Ni}$ & $\mathrm{Pb}$ & $\mathrm{Zn}$ \\
\cline { 2 - 10 } & $(\mathrm{mg} / \mathrm{L})$ & $(\mu \mathrm{g} / \mathrm{L})$ & $(\mu \mathrm{g} / \mathrm{L})$ & $(\mu \mathrm{g} / \mathrm{L})$ & $(\mu \mathrm{g} / \mathrm{L})$ & $(\mathrm{mg} / \mathrm{L})$ & $(\mathrm{mg} / \mathrm{L})$ & $(\mu \mathrm{g} / \mathrm{L})$ & $(\mu \mathrm{g} / \mathrm{L})$ & $(\mathrm{mg} / \mathrm{L})$ \\
\hline $\mathrm{R} 6$ & $<0.06$ & 3.2 & $<1.0$ & $<2$ & $<2$ & $<0.03$ & 0.28 & $<5$ & $<3$ & $<0.05$ \\
$\mathrm{I} 1$ & 26 & 1.3 & 310 & 120 & 2,800 & 17 & 4.2 & 61 & 3 & 15 \\
$\mathrm{I} 4$ & $<0.06$ & 1.1 & 3.8 & 29 & 50 & 0.05 & 1.9 & 11 & $<3$ & 1.8 \\
$\mathrm{I5}$ & $<0.06$ & 2.3 & 2.3 & 13 & $<50$ & 0.06 & 0.66 & 9 & $<3$ \\
\hline
\end{tabular}

maintain organisms under optimal conditions to be used in feeding assays, increasing flexibility when scheduling toxicity tests. Within the dimension boundaries tested in the present study, a very narrow range of snail size is not mandatory for toxicity testing because neither differences on feeding rates between size classes, nor correlations between size and feeding were found.

\section{Endpoint sensitivity}

Theodoxus fluviatilis proved to be very sensitive to lethal concentrations of cadmium, with 48-h and 96-h LC50 values of $103 \mu \mathrm{g} / \mathrm{L}$ and $64 \mu \mathrm{g} / \mathrm{L}$, respectively; this sensitivity was 6 times to 50 times more than that of other freshwater snails, namely, Physa acuta (48-h LC50 = $1050 \mu \mathrm{g} / \mathrm{L}$ [41]), Lymnaea stagnalis (48-h LC50 = 583 $\mu \mathrm{g} / \mathrm{L}$ [42]), and Filopaludina martensi $(48-\mathrm{h} \quad \mathrm{LC} 50=5010$ and $96-\mathrm{h} \quad \mathrm{LC} 50=2330 \mu \mathrm{g} / \mathrm{L} \quad$ [43] $)$, and was the same as that of Aplexa hypnorum (96-h LC50 = $93 \mu \mathrm{g} / \mathrm{L}[44])$.

After $48 \mathrm{~h}$ of exposure, feeding of $T$. fluviatilis was marginally more sensitive to cadmium than survival, with EC50 and EC20 values being 1.2 times and 1.9 times lower than LC50 and LC20 values, respectively. The former difference1.2 times-was somehow unexpected, given that previous studies found larger differences between both endpoints for other invertebrates, namely, the estuarine crab Carcinus maenas (6.5 times [10]) also with cadmium and, with copper, the polychaete Hediste diversicolor (4.6 times [7]), the estuarine mudsnail $H$. ulvae (over 2.7 times [13]), and the freshwater amphipod Echinogammarus meridionalis (2.2 times [19]). The possibility that physiological recovery was responsible for such a small difference found in the present study cannot be ruled out and, thus, further studies are needed to unravel this issue.

After a short-term exposure to cadmium, lethality and feeding depression of the survivors because of cadmium would seem to contribute evenly to consumption inhibition at the population level because the sensitivity of both responses was similar. Therefore, the novel toxicity parameter $[13,19]$ - the immediate inhibition of population consumption-becomes pertinent to assess cadmium effects at higher levels of biological organization. In addition, such an ecosystem toxicity parameter may very likely contribute to reducing uncertainties in extrapolations inherent to ecological risk assessment, namely, those most commonly made from the results of relatively simple laboratory assays to quantify ecosystem-level effects. Two techniques were used, each having advantages and disadvantages. With the first technique, the popEC50 is computed by multiplying, for each concentration, the individual feeding by the survival proportion, with the advantage of allowing the computation of confidence limits. However, it increases the chance of violating the homoscedasticity assumption in regression, with means being positively correlated with respective variances, because a strong association between feeding depression and mortality is expected. The second technique overcomes this drawback because it integrates the concentration-response relationships for feeding and for survival from independent tests. However, it assumes that there is no correlation between the tolerance among individuals to sublethal (feeding) and lethal levels of a toxicant. Violating this assumption may lead to a biased estimation of risk. For instance, if organisms more sensitive to feeding depression are those dying earlier, then the survivors will feed at a higher rate than the average of the initial population, thus partially compensating at the population level for the loss of some individuals (the dead ones) $[13,19]$. Both techniques led to very close 48 -h population consumption EC50 estimates $(69 \mu \mathrm{g} / \mathrm{L}$ and $67 \mu \mathrm{g} / \mathrm{L}$ of cadmium), corroborating the findings of Krell et al. [13] (75 $\mu \mathrm{g} / \mathrm{L}$ and $68 \mu \mathrm{g} / \mathrm{L}$ of copper) and Agostinho et al. [19] (187 $\mu \mathrm{g} / \mathrm{L}$ and $168 \mu \mathrm{g} / \mathrm{L}$ of copper) for a mudsnail and an amphipod, respectively. At the 48-h LC20, the immediate inhibition of population consumption would be $53 \%$, which corresponds to an expectedly strong disruption of ecosystem functioning.

\section{Influence of exposure conditions on postexposure feeding}

The influence of environmental conditions, other than contamination, on postexposure feeding was investigated because they might act as confounding factors, especially during in situ assays [7,9,13]. Feeding was not affected by current velocity, hardness, conductivity, sediment organic matter content, sediment particle size distribution, and their combinations, allowing direct comparisons among sites within tested ranges. Temperature did not influence postexposure feeding, but the range among reference sites was very narrow. This parameter was found to be significant in other studies [7,13,16]; thus, caution is advised if sites with different temperatures are to be assayed.

\section{Postexposure feeding assays with contaminated natural waters}

To evaluate the effectiveness of the in situ assay, organisms were deployed at 1 reference site (R6) and at 5 sites (I1-I5) impacted by acid mine drainage, within the same river basin. Given that, among the impacted sites, live organisms (63\%) were recovered only at the site located furthest downstream from the dilution gradient of the mine effluent (I5), only this site could be used to evaluate feeding. Here, a severe depression-of $46 \%$ was found, corroborating feeding as a potentially responsive sublethal endpoint. Moreover, the immediate effect on consumption at the population level, through the integration of survival and feeding at I5, would be $71 \%$, which presumes an intense impairment on ecosystem functioning.

\section{CONCLUSIONS}

The short-term sublethal laboratory and in situ assay based on postexposure feeding of the freshwater snail T. fluviatilis proved to be a potentially valuable tool to be added to the battery of assays developed in recent years to assess contaminant effects in 
freshwater aquatic systems, particularly in rivers. The species T. fluviatilis was easy to collect, transport, maintain under laboratory cultures, and manipulate, and has a key role in the functioning of river ecosystems, all essential characteristics for its proposal as a test species. The methodologies for in situ deployment and retrieval of the organisms and for quantification of postexposure feeding rates are simple, demand little time and effort, are thus inexpensive, and allow a rapid estimation of the response of snails to contaminants. These are critical aspects for the assessment and monitoring of environmental quality, especially now, in the context of the European Union's Water Framework Directive [45]. The integration of feeding and survival into a single parameter-the immediate inhibition of population consumption-may be useful to provide a more relevant evaluation of potential toxicant impacts at the population level and thus of key ecosystem processes.

Acknowledgment-The present study was funded by the Fundação para a Ciência e a Tecnologia (Portugal) through the FRAMEFFECTIVE and ECOTOXTOOLS projects (contracts PTDC/AAC-AMB/105411/2008 and PTDC/AAC-AMB/103547/2008, respectively) and through Ciência 2007Human Potential Operational Program and Quadro de Referência Estratégico Nacional through European Social Fund and Ministry of Education and Science funds.

\section{REFERENCES}

1. Wallace JB, Webster JR. 1996. The role of macroinvertebrates in stream ecosystem function. Annu Rev Entomol 41:115-139.

2. Maltby L. 1999. Studying stress: The importance of organism-level responses. Ecol Appl 9:431-440.

3. Forrow DM, Maltby L. 2000. Toward a mechanistic understanding of contaminant-induced changes in detritus processing in streams: Direct and indirect effects on detritivore feeding. Environ Toxicol Chem 19:2100-2106.

4. Maltby L, Kedwards TJ, Forbes VE, Grasman K, Kammenga JE, Munns WR Jr, Ringwood AH, Weis JS, Wood SN. 2001. Linking individuallevel responses and population-level consequences. In Baird DJ, Burton Jr GA, eds Ecological Variability: Separating Natural from Anthropogenic Causes of Ecosystem Impairment. SETAC, Pensacola, FL, USA, pp 27-82.

5. McLoughlin N, Yin D, Maltby L, Wood RM, Yu H. 2000. Evaluation of sensitivity and specificity of two crustacean biochemical biomarkers. Environ Toxicol Chem 19:2085-2092.

6. McWilliam RA, Baird DJ. 2002. Postexposure feeding depression: A new toxicity endpoint for use in laboratory studies with Daphnia magna. Environ Toxicol Chem 21:1198-1205.

7. Moreira SM, Moreira-Santos M, Guilhermino L, Ribeiro R. 2005. A short-term sublethal in situ toxicity assay with Hediste diversicolor (Polychaeta) for estuarine sediments based on postexposure feeding. Environ Toxicol Chem 24:2010-2018.

8. Allen Y, Calow P, Baird DJ. 1995. A mechanistic model of contaminantinduced feeding inhibition in Daphnia magna. Environ Toxicol Chem 14:1625-1630.

9. Maltby L, Clayton SA, Wood RM, McLoughlin N. 2002. Evaluation of the Gammarus pulex in situ feeding assay as a biomonitor of water quality: Robustness, responsiveness, and relevance. Environ Toxicol Chem 21:361-368.

10. Moreira SM, Moreira-Santos M, Guilhermino L, Ribeiro R. 2006. An in situ postexposure feeding assay with Carcinus maenas for estuarine sediment-overlying water toxicity evaluations. Environ Pollut 139: 318-329.

11. Satapornvanit K, Baird DJ, Little DC. 2009. Laboratory toxicity test and post-exposure feeding inhibition using the giant freshwater prawn Macrobrachium rosenbergii. Chemosphere 74:1209-1215.

12. Crichton C, Conrad A, Baird DJ. 2004. Assessing stream grazer response to stress: A post-exposure feeding bioassay using the freshwater snail Lymnaea peregra (Müller). Bull Environ Contam Toxicol 72:564-570.

13. Krell B, Moreira-Santos M, Ribeiro R. 2011. An estuarine mudsnail in situ toxicity assay based on post-exposure feeding. Environ Toxicol Chem 30:1935-1942.

14. Soares S, Moreira S, Andrade S, Guilhermino L, Ribeiro R. 2005. Freshwater-saltwater interface and estuarine sediment in situ assays based on post-exposure feeding of chironomids and polychaetes. Estuaries 28:314-319.

15. Rosen G, Miller K. 2011. A postexposure feeding assay using the marine polychaete Neanthes arenaceodentata suitable for laboratory and in situ exposures. Environ Toxicol Chem 30:730-737.

16. Soares S, Cativa I, Moreira-Santos M, Soares AMVM, Ribeiro R. 2005 A short-term sublethal in situ sediment assay with Chironomus riparius based on postexposure feeding. Arch Environ Contam Toxicol 49: $163-172$.

17. Castro BB, Sobral O, Guilhermino L, Ribeiro R. 2004. An in situ bioassay integrating individual and biochemical responses using small fish species. Ecotoxicology 13:667-681.

18. Moreira SM, Moreira-Santos M, Rendón-von Osten J, da Silva EM, Ribeiro R, Guilhermino L, Soares AMVM. 2010. Ecotoxicological tools for the tropics: Sublethal assays with fish to evaluate edge-of-field pesticide runoff toxicity. Ecotoxicol Environ Saf 73:893-899.

19. Agostinho M, Moreira-Santos M, Ribeiro R. 2012. A freshwater amphipod toxicity test based on postexposure feeding and the population consumption inhibitory concentration. Chemosphere 87:43-48.

20. Burton GA, Greenberg MS, Rowland C, Irvine CA, Lavoie DR, Brooker JA, Moore L, Raymer DFN, McWilliam RA. 2005. In situ exposures using caged organisms: A multi-compartment approach to detect aquatic toxicity and bioaccumulation. Environ Pollut 134:133-144.

21. Liber K, Goodfellow W, Besten PD, Clements W, Galloway T, Gerhardt A, Green A, Simpson S. 2007. In situ-based effects measures: Considerations for improving methods and approaches. Integr Environ Assess Manag 3:246-258.

22. Crane M, Burton GA, Culp JM, Greenberg MS, Munkittrick KR, Ribeiro R, Salazar MH, St-Jean SD. 2007. Review of aquatic in situ approaches for stressor and effect diagnosis. Integr Environ Assess Manag 3: 234-245.

23. Lodge DM. 1986. Selective grazing on periphyton: A determinant of freshwater gastropod microdistributions. Freshwater Biol 16:831-841.

24. Reed WL, Janzen FJ. 1999. Natural selection by avian predators on size and colour of a freshwater snail (Pomacea flagellata). Biol J Linn Soc 67:331-342.

25. Ruehl CB, Trexler JC. 2011. Comparison of snail density, standing stock, and body size between Caribbean karst wetlands and other freshwater ecosystems. Hydrobiologia 665:1-13.

26. Brönmark C. 1989. Interactions between epiphytes, macrophytes, and freshwater snails: A review. J Mollus Stud 55:299-311.

27. Zettler ML, Frankowski J, Bochert R, Röhner M. 2004. Morphological and ecological features of Theodoxus fluviatilis (Linnaeus, 1758) from Baltic brackish water and German freshwater populations. $J$ Conchol 38:305-316.

28. Bunje PME. 2005. Pan-European phylogeography of the aquatic snail Theodoxus fluviatilis (Gastropoda: Neritidae). Mol Ecol 14:4323-4340.

29. Kirkegaard J. 2006. Life history, growth and production of Theodoxus fluviatilis in Lake Esrom, Denmark. Limnologica 36:26-41.

30. Graça MAS, Serra SRQ, Ferreira V. 2012. A stable temperature may favour continuous reproduction by Theodoxus fluviatilis and explain its high densities in some karstic springs. Limnetica 31:129-140.

31. Feio MJ, Alves T, Boavida M, Medeiros A, Graça MAS. 2010. Functional indicators of stream health: A river-basin approach. Freshwater Biol 55:1050-1065.

32. ASTM International. 2002. Standard guide for conducting acute toxicity tests on test materials with fishes, macroinvertebrates, and amphibians. In Annual Book of ASTM Standards, Vol 11.05. Philadelphia, PA, USA, pp 729-796

33. American Public Health Association, American WaterWorks Association, Water Pollution Control Federation. 1995. Standard Methods for the Examination of Water and Wastewater. American Public Health Association, 19th ed. Washington, DC.

34. Buchanan JB, Kain JM. 1971. Measurement of the physical and chemical environment. In Holme NA, McIntyre AD, eds Methods for the Study of Marine Benthos. Blackwell Scientific, Oxford, UK, pp $30-58$.

35. Feio MJ, Reynoldson TB, Ferreira V, Graça MAS. 2007. A predictive model for freshwater bioassessment (Mondego River, Portugal). Hydrobiologia 589:55-68.

36. Lopes I, Gonçalves F, Nogueira A, Soares AMVM, Ribeiro R. 2000. Field validation of specific ecotoxicological tools for aquatic systems impacted with acid mine drainage. Int J Environ Stud 58:3-20.

37. Zar JH. 1996. Biostatistical Analysis. Prentice Hall, Upper Saddle River NY, USA.

38. Organization for Economic Cooperation and Development. 1998 Report of the OECD Workshop on Statistical Analysis of Aquatic Toxicity Data. Paris, France. 
39. Brent RN, Herricks E. 1998. Postexposure effects of brief cadmium, zinc, and phenol exposures on freshwater organisms. Environ Toxicol Chem 17:2091-2099.

40. Shipp E, Grant A. 2006. Hydrobia ulvae feeding rates: A novel way to assess sediment toxicity. Environ Toxicol Chem 25:3246-3252.

41. Cheung CCC, Lam PKS. 1998. Effect of cadmium on the embryos and juveniles of a tropical freshwater snail, Physa acuta (Draparnaud, 1805). Water Sci Technol 38:263-270.

42. Slooff W. 1983. Benthic macroinvertebrates and water quality assessment: Some toxicological considerations. Aquat Toxicol 4:73-82.
43. Piyatiratitivorakul P, Boonchamoib P. 2008. Comparative toxicity of mercury and cadmium to the juvenile freshwater snail Filopaludina martensi martensi. ScienceAsia 34:367-370.

44. Holcombe GW, Phipps GL, Marier JW. 1984. Methods for conducting snail (Aplexa hypnorum) embryo through adult exposures: Effects of cadmium and reduced $\mathrm{pH}$ levels. Arch Environ Contam Toxicol 13 627-634.

45. Allan IJ, Vrana B, Greenwood R, Mills GA, Roig B, Gonzalez C. 2006. A "toolbox" for biological and chemical monitoring requirements for the European Union's Water Framework Directive. Talanta 69:302-322. 